\title{
Selected Papers
}

\section{Annual Meetings, SAEA, Little Rock, Arkansas, February 1998}

TITLE: Analysis of Pest Management Strategies (Moderator: Kelly Bryant, Univ. of Ark.).

Economic Analysis of Genetically Engineered Bt Cotton for Tobacco Budworm and Bollworm Control. Steve Slinsky, Elizabeth $R$. Edens, James A. Larson, Roland $K$. Roberts, and Gary L. Lentz, Univ. of Tenn.

The objective of this study was to compare the cost of conventional control of tobacco budworms and cotton bollworms with the cost of genetically engineered Bt cotton. Tobacco budworm and bollworm control expenditures reported by Tennessee farmers in a 1997 survey were used to estimate the cost of conventional control.

Combining Contingent and Actual Data in Evaluating Adoption of Bt Cotton in the Southeast. Michele Marra, B. Hubbell, and G. Carlson, N.C. State Univ.

We combine market data on adoption of $\mathrm{Bt}$ cotton with contingent data on willingness to adopt at varying technology prices. While the actual price was set at $\$ 32$ /acre in 1996 , analysis of the contingent adoption data indicated that cotton growers have a mean willingness to pay for $\mathrm{Bt}$ cotton of between $\$ 22$ and $\$ 40$.

Optimal IPM Strategies in Missouri Soybean Production. Kostas Iliopoulos, $\mathrm{N}$. $\mathrm{Ka}$ laitzandonakes, and I. Theodorakopoulou, Univ. of Mo.

A major pest confronting Missouri soybean producers is the soybean cyst nematode
(SCN), Heterodera glycines. The study derives and discusses optimal strategies for Missouri soybean farmers confronted with SCN infestations. It also demonstrates the effectiveness of IPM strategies, especially when the dynamic elements of pest control are considered (e.g., population dynamics).

Pest Management Profiles of Atlanta Lawn Care and Landscape Maintenance Firms. Wojciech Florkowski, B. Hobbell, R. Oetting, S. K. Braman, and C. Robacker, Univ. of Ga.

Using cluster analysis, four groups of firms were identified, ranging from conventional chemical-intensive firms to alternative management-intensive firms. Multinomial logit analysis revealed that ownership, size, equipment value, and years in business, as well as the age and education of the owner/manager, were all significant determinants of cluster membership.

TITLE: Commodity Marketing (Moderator: Clem Ward, Okla. State Univ.).

Substituting Soybean Oil for Petroleum Oil and Synthetic Insecticides in Fruit Production: Economic Impacts on the Soybean Sector. Robert Pendergrass, Roland K. Roberts, Daniel de la Torre Ugarte, Daryll E. Ray, Dennis Deyton, and Carl Sams, Univ. of Tenn.

Research has shown that soybean oil is an effective, environmentally friendly alternative to petroleum oil in fruit production. Nationallevel economic impacts of fruit farmers' adoption of soybean oil spray are examined. Re- 
sults indicate that oil stocks will decline and soybean prices will change only slightly.

Hedonic Prices of Malawi Burley Tobacco. Duncan Samikwa, L. Sanders, and B. Wade Brorsen, Okla. State Univ.

This paper reports the results of a study to discover the contribution of quality to price variation for tobacco. Research was conducted on the Malawi burley tobacco auction market. Leaf characteristics relating to quality were identified and evaluated using the hedonic method. Results indicate factors affecting the price received for burley tobacco include reputation of the producer, month of auction, and lot size.

Can Markets for Homogeneous Products Be Segmented? An Empirical Test of Vegetable Markets in Indonesia. S. Sureshwaran, S.C. State Univ.; K. Selvavel, Clafin Univ.; G. Hanks, S.C. State Univ.; and J. Nyankori, Clemson Univ.

Geographic variables offer the only opportunity for market segmentation in homogeneous products. Indonesia is used as a case study because of its unusual geographical structure and density of population. Granger causality tests of wholesale prices in different cities suggest that vegetable markets are efficient.

Alternative Agricultural Crops. Joey Mehlhorn and Lisa House, Miss. State Univ.

The derived demand for woodpulp from newsprint production was estimated. The model found that woodpulp was not responsive to its own price or the price of ONP. As a result, the potential for using kenaf as a substitute for woodpulp may be limited at this time.

TITLE: Distributional Issues in Agro-environmental Policy (Moderator: Craig Infanger, Univ. of Ky.).

Economic Impacts of EQIP on Central Tex- as Dairies. Robert H. Neal, Northeast La. Univ.

Even if the agencies assigning EQIP eligibility adopt strict interpretation of EQIP legislation, small- and medium-sized dairies will experience no significant improvement in their net returns to equity, risk, and management if the regulation generates no significant waste disposal costs. They realize 14-34\% improvement if the regulation requires capital-intensive improvements such as composting.

The Impact of Pesticide Legislation on the U.S. Tomato Industry. C. M. Brewster, T. H. Spreen, and M. S. Deepak, Univ. of Fla.

A spatial equilibrium model is used to determine the impact of banning three pesticides used in U.S. tomato production. In the short run, producer incomes and consumer welfare are affected negatively. Production is redistributed within the U.S., and Mexican producers improve their competitive position. Long-run effects are indeterminate.

Wetlands and Their Effects on Rural Land Values. John E. Reynolds and A. Regalado, Univ. of Fla.

Location, parcel size, capital improvements, proportion of land in intensive uses, and the proportion of land in different types of wetlands explained $81.6 \%$ of the variation in rural land sales prices. The presence of wetlands may have either a positive or negative effect, depending on the type of wetland.

Effluent Allowance Trading and Agriculture: Issues and Options. Patricia E. Norris, Mich. State Univ.; and Kurt Stephenson, Va. Tech.

Trending away from traditional command and control regulations toward market-oriented approaches, regulatory agencies are investigating alternative strategies for meeting water quality goals. Effluent allowance trading is one example. Success at integrating agricultural nonpoint sources in trading programs de- 
pends on characteristics of the sources and the agricultural and environmental policy context.

TITLE: Quantitative Methods (Moderator: Dan Tilley, Okla. State Univ.).

Why Is Convex Set Stochastic Dominance Seldom Used? Francis McCamley and Richard K. Rudel, Univ. of Mo.

Even though set stochastic dominance (CSD) can sometimes improve the efficiency of stochastic dominance criteria, it is seldom used. This paper suggests several reasons for the limited use of CSD. Some of our ideas are illustrated by applying five stochastic dominance criteria to a set of 11 probability distributions.

The Overlapping Data Problem. Ardian Harri and B. Wade Brorsen, Okla. State Univ.

The conventional estimation approach with overlapping data is to use the Newey-West estimating procedure. We argue in favor of using generalized least squares (GLS) instead. Monte Carlo results show that the Newey-West procedure has considerably larger variances of parameter estimates and lower power than GLS. Hypothesis tests using the Newey-West procedure also have incorrect size, even with sample sizes as large as 1,000.

Econometric Methods for Nonstationary Economic Time Series. Hector O. Zapata, La. State Univ.

The econometric literature on estimation methods with nonstationary and possibly cointegrated economic time series over the past decade is summarized in a context useful to applied researchers. A guide to the literature is presented and several books are briefly reviewed. A discussion on some popular software packages is provided.

TITLE: Analyzing Costs and Decision Support Systems in Crop Production (Moderator: Steve Isaacs, Univ. of $\mathrm{Ky}$.).
Effects of Machine-Labor Fixity on Optimum Cropping Decisions. Joseph A. Atwood, Mont. State Univ.; and G. Helmers, Univ. of Nebr.

Short-run cropping decisions can be considerably different among producers. One reason for this is the different fixed machine-labor sets among producers. Differences in short-run cropping decisions arising from alternative fixed resource sets are examined, exhibiting considerable difference by set.

Accuracy of a Simplified Procedure of Generating Long-Term Costs in Crop Budgets. Roger A. Selley and G. Helmers, Univ. of Nebr.; and J. Atwood, Mont. State Univ.

It has been difficult to accurately include long-term cost items (machine ownership and labor) in crop cost budgets. A method is developed where a limited number of long-run costs are estimated by crop using integer programming. For any crop mix, the long-run costs are then found by a weighted average.

Transferability of Research Recommendations: A Case Study of Arkansas Soybean Production. Carl R. Dillon and C. Oriade, Univ. of Ark.

Declining resources available to research strengthen the need to more fully comprehend the suitability of transferring research recommendations across sites and conditions. Analysis of profitability and production risk indicates a potential for direct transfer of some production recommendations and the ability to modify others for Arkansas soybean production.

Development and Potential Extension of an Economic and Financial Decision Support Aid for Cotton Producers. Lawrence Falconer and Joe Outlaw, Tex. A\&M Univ. Res. and Ext. Center.

Uncertain yield potential and changing market conditions make the use of traditional economic thresholds for certain treatments 
problematic for cotton producers. This decision aid incorporates uncertainty analysis with ICCEM yield projections or subjective yield projections with: (1) cash flows for financial feasibility analysis, and (2) cost/benefit analysis for in-season decisions on resource utilization.

TITLE: Advertising and Promotion (Moderator: Rodney Holcomb, Okla. State Univ.).

\section{Voluntary Producer Contributions to Com-} modity Research and Promotion Programs. Dan S. Tilley, K. Crowley, and S. Henneberry, Okla. State Univ.

A theory about why producers elect to participate or not participate in voluntary commodity research and promotion programs is presented. An existing model is augmented by the theory of social sanctions as presented by Coleman and others.

Dynamic Effects of Peanut Butter Advertising on Peanut Butter Demand. Satish $Y$. Deodhar and Stanley M. Fletcher, Univ. of Ga.

Using an error correction approach and nonlinear three-stage least squares, long-run and short-run effects of aggregate brand advertising on the U.S. demand for peanut butter are estimated. Results indicate that demand for peanut butter is more responsive to advertising in the long run. Moreover, demand is responsive to price only in the short run.

Relationship Between Advertising and Sales of Tennessee Nursery Crops. Enefiok Ekanem, S. Singh, and F. Tegegne, Tenn. State Univ.

Advertising is an important marketing function in the nursery industry. Eighty-nine percent of growers surveyed spent an average of $4 \%$ of gross sales on advertising. Trade shows, trade magazines, and word of mouth represented most frequently used advertising tools. Ordinary least squares regression showed a significant relationship between sales and advertising.

Measurement of Advertising Effort: The Issue Revisited. Seong-Cheon Seo, Oral Capps, Jr., and David A. Bessler, Tex. A\&M Univ.

Using IRI Infoscan national-level data for Prego spaghetti sauce, we investigate the better measure of TV advertisement, either total dollar outlay or gross ratings points (GRPs). Econometrically, neither measure is statistically superior. However, based on tests of Granger causality, dollar spending precedes GRPs, but not vice versa.

TITLE: Dairy and Livestock Management Issues (Moderator: Lee Meyer, Univ. of Ky.).

A Conjoint Analysis on the Decision to Retain Ownership of Weaned Calves. David J. Englund and Scott W. Fausti, S. Dak. State Univ.

Conjoint analysis is typically used to discover consumer preferences. Our study uses this procedure to examine choices made on the supply side of the beef industry. Attributes that lead cow-calf producers to retain ownership of their weaned calves are discovered to provide incentive for other producers to adopt the practice.

A Markov Chain Analysis of Changes in Farm Size in the Louisiana Dairy Industry. Noro Rahelizatovo and Jeffrey M. Gillespie, La. State Univ.

Over the period 1981-95, the number of dairy farms in Louisiana decreased $35 \%$, while average farm size increased. This study examines the changing structure of the dairy industry using a nonstationary Markov chain analysis utilizing micro data. Factors influencing structural changes include government policies, the macroeconomic environment, and prices.

The Economics of Pasture-Based Dairying in the Southeast: A Review of the Evidence. 
G. A. Benson, S. P. Washburn, and J. P. Green, N.C. State Univ.

Work in North Carolina and elsewhere suggests small differences in profitability between confinement herds and cows on pasture. Profits vary widely among farms of the same type. We conclude that the profitability of grazing will be site specific, and profits and cash flows should be projected before switching to grazing.

TITLE: International Issues: Small Farms, Investments, and Reforms (Moderator: Albert Allen, Miss. State Univ.).

Location-Specific Determinants of U.S. Direct Foreign Investment in the Caribbean. Pooran Lall, David W. Norman, and Allen M. Featherstone, Kans. State Univ.

This study compares the relationships between locational factors and U.S. direct foreign investment (DFI) between Caribbean and Latin American countries (1984-94). Market size and growth rate, exchange rate, and literacy rate had a stronger positive, while taxes on DFI firms' income had a stronger negative correlation with U.S. DFI in the Caribbean.

Measuring the Gains from Market-Based Reforms: The Case of the Sugar Industry in Veracruz, Mexico. Gretchen Greene, Charles B. Moss, and Thomas Spreene, Univ. of Fla.

The Mexican sugar industry has undergone significant and simultaneous market-based reforms such as privatization of sugar mills, and a new system of sugarcane payment based on quality rather than quantity. This study explores the recent improvements in productivity in the field in light of the market-based reforms.

Micro- and Small-Scale Enterprises: A Study of Factors Influencing Entrepreneurship in Rural Java, Indonesia. Surendra $P$. Singh and E. Ekanem, Tenn. State Univ.
This paper explores the characteristics and structure of micro- and small-scale enterprises (MSEs), and examines characteristics and attitudes/perceptions of entrepreneurs using a survey of 200 enterprises in Java, Indonesia. Results from Chi-square and $t$-tests indicate that programs intended to assist MSEs must be carefully tailored to reflect differences among enterprises and entrepreneurs.

Identification of Problems on Small Farms in South Africa. Ebenezer F. Kolajo and Neil R. Martin, Jr., Auburn Univ.

This paper identifies the problems typically faced by small farms in South Africa and develops an index to rank the problems for needs evaluation and assistance. A structured questionnaire was administered to 106 randomly selected farm households in two districts. The highest ranked problem was drought, followed by high input prices.

TITLE: Issues in Production Economics (Moderator: Joseph E. Williams, Okla. State Univ.).

Differences in Winter Wheat Production Practices Across Intended Use. Randy $R$. True and Francis M. Epplin, Okla. State Univ.

This study was conducted to determine the proportion of Oklahoma wheat acres used for grain only, for forage only, and for both forage and grain, and to determine if production practices differ across use. Our findings show production practices vary depending upon the intended use. USDA data do not reflect differences in use.

Marginal and Average Cost Analysis of NoTill Crop Production. Ray Massey, Univ. of Mo.

This paper discusses the methodology of analyzing no-till crop production intended for extension to farmers. Average and marginal, cash and noncash, and fixed and variable costs associated with no-till adoption are analyzed. Economic benefits of no-till will not match 
farmer experiences due to the dynamic process and misunderstanding of cost concepts.

Farm-Level Economic Effects of Roundup Ready $^{\mathrm{TM}}$ Soybeans. Roland $K$. Roberts, Robert Pendergrass, and Robert M. Hayes, Univ. of Tenn.

Roundup Ready ${ }^{\mathrm{TM}}$ soybeans can provide producers with a new alternative for controlling weeds. The profitability of Roundup Ready soybeans and breakeven yields of other varieties required for equivalent returns are examined. Results indicate that Roundup Ready soybeans potentially can improve the profitability and financial conditions of soybean producers.

An Economic Analysis of Four Tillage Procedures for the Control of Salinity Damage in Rice. Alan D. Pearce, C. R. Dillon, C. E. Wilson, T. C. Kiesling, and D. Frizzell, Univ. of Ark.

Economic analysis was conducted on an agronomic experiment performed during 1995 and 1996 by the University of Arkansas. It was determined that all tillage practices (excluding no-tillage) used in the experiment caused similar results in rice. Therefore, tillage in any form should improve yields and net returns.

TITLE: Prices and Risk Management (Moderator: B. Wade Brorsen, Okla. State Univ.).

A Stochastic Dominance Analysis of Retained Ownership and Alternative Pricing Strategies for Feeder Cattle. James A. Larson, Dan McLemore, Emmit L. Rawls, and David E. Sleigh, Univ. of Tenn.

This study evaluates the expected value and variability of net revenues for retained ownership and alternative futures contract and put option pricing strategies for feeder cattle. The most profitable backgrounding system is small grain pasture, and the most profitable backgrounding/custom feeding system begins with fescue pasture. For most levels of risk aversion, farmers would require a large risk premium to undertake the best hedging or put option strategy.

Estimated Value of Vertical Coordination in the Fed Cattle Market. John D. Anderson, James N. Trapp, Clement E. Ward, and Derrell S. Peel, Okla. State Univ.; and Stephen $R$. Koontz, Mich. State Univ.

The Fed Cattle Market Simulator (FCMS) was used to measure the benefits of nonprice coordination of marketing/purchasing in the fed cattle market. Coordination strategies which keep feedlot marketings current result in significant gains in industry profits. These strategies reduce feedlot costs while increasing boxed beef prices.

Factors Influencing Cash Marketing Decisions for Fed Cattle. Steve Schamber, Steve Fausti, and Dwight Adamson, S. Dak. State Univ.

The reason for the failure of individual carcass-based pricing systems to supplant average-price-based pricing systems in the cash market for fed cattle remains unresolved. Competing hypotheses in the literature associated with this issue are empirically tested using survey data collected on the marketing behavior of cattle producers.

Employing Stochastics, the Relative Strength Index, and Moving Averages as Indicators for Technical Analysis in Futures Market Trading. Roger Reed and Jeff Beaulieu, Southern Ill. Univ.

Technical trading with oscillators, stochastics, and the relative strength index is simulated in 384 trading variations of corn and soybean contracts. Positive gross returns are generated in 186 trading variations, and significantly positive net returns in 49 . Additional research as to why specific variations did not result in significant positive net returns is recommended. 
TITLE: Policy Implications of Pesticide Use in Agriculture (Moderator: Nicholas Kalaitzandonakes, Univ. of Mo.).

Pest Management, Net Revenue Risk, and Insurance: What Are the Policy Alternatives? John Robinson, Barry J. Barnett, and Stan Spurlock, Miss. State Univ.

A farm-level simulation model was used to study the effect of variable insect control costs as a source of net revenue risk for a typical Mid-South farming system. Crop insurance products did not protect against insect control cost variability. Alternative risk management tools are considered.

An Analysis of the Welfare Impact of Discontinuing the Use of Selected Pesticides in U.S. Rice Production. Eddie C. Chavez, Eric J. Wailes, and Gail L. Cramer, Univ. of Ark.

Discontinuing the use of 2,4-D, carbofuran, and benomyl in U.S. rice production would result in welfare losses. Consumer loss exceeds producer gain as the magnitude of the price increase exceeds the yield decline. Welfare losses range from $\$ 12-\$ 55$ million without substitutes, and from $\$ 5-\$ 10$ million with substitutes.

Factors Influencing the Public's Concern with Agricultural Production Activity and Human Health. Mack C. Nelson and Yvonne B. Oliver, Fort Valley State Univ., Ga.

A logit model was used to examine the influence of socioeconomic and belief factors on respondents' concerns with agricultural production and human health using a national survey data set. Results suggest that concern is significantly influenced by race, sex, age, and belief about farmers and farming activities.

TITLE: Quantitative Methods: Applications in Production Economics (Moderator: John Reynolds, Univ. of Fla.).

Consistency of Production Choices Under Expected Value-Variance and Direct Utility
Models: An Empirical Investigation. Caleb $A$. Oriade and Carl R. Dillon, Univ. of Ark.

The study investigates the suitability of the expected value-variance method for approximating expected utility. Its optimal production choices are compared to direct utility outcomes using quality indexes of utility losses. Results corroborate the increasing evidence of consistency between expected value-variance and expected utility choices if the estimation parameters are carefully specified.

TITLE: Multi-Sectoral Models: Approaches and Applications (Moderator: David Freshwater, Univ. of Ky.).

Assessing the Impact of Value-Added Forest Products on a Regional Economy with a Modified Social Accounting Matrix. David W. Hughes, La. State Univ.

This research focuses on estimating the impacts of feasible growth in the value-added forest products industry on the economy of a 10-parish region in northwest Louisiana. A social accounting matrix (SAM), generated in IMPLAN, is modified through the use of an industry occupation matrix. The modified SAM is used to estimate growth in employment and income in the region.

Deskilling in Rural Labor Markets of the Southeast: A Measure and Examination of Its Variation. Timothy $R$. Wojan, Univ. of $K y$.

A method is developed identifying the relative specialization of local labor markets in various occupations. Attention is focused on examining characteristics of labor markets associated with increased specialization in lowand high-skill occupations. This empirical assessment facilitates the development of human resource policy in rural areas.

Economic Development Impacts from Increased Efficiency in the Food and Kindred Products Sector for Oklahoma. Aleligne $K$. Amera and Dean F. Schreiner, Okla. State Univ. 
A computable general equilibrium (CGE) model consisting of three household income groups and 30 sectors was developed to evaluate state economic development impacts from a $10 \%$ increase in the efficiency of all food processing industries. Short- and longrun impacts on household welfare, gross state product, employment, and commodity and factor markets were evaluated.

Estimating the Regional Economic and Welfare Impacts of Natural Climatic Variability: An Application to the 1995-96 Oklahoma Drought. Larry D. Sanders, Edgar F. Pebe Diaz, and Michael R. Dicks, Okla. State Univ.

A regional computable general equilibrium (CGE) model is used to estimate the economic and welfare impacts to the Oklahoma state economy from the 1995-96 drought. Results show that agricultural output variations attributable to drought have relatively small negative effects on the Gross State Product (GSP) and household welfare.

TITLE: Agricultural and Food Policies Affecting International Trade (Moderator: Mary Marchant, Univ. of Ky.).

United States Policy Evaluation Methodology: A Policy Analysis Approach. Nolan Quiros and Michael Dicks, Okla. State Univ.

The producer subsidy equivalent (PSE) is an indicator of government transfers to agricultural producers. Its information enables policy makers to monitor levels of support among countries. From the PSE indicator, a policy evaluation methodology (PEM) is developed to evaluate and compare impacts on level changes and transfer methods of domestic agricultural policies.

Nontariff Trade Barriers and Political Solutions to Trade Disputes: A Case Study of U.S. Poultry Exports to Russia. Glenn C. W. Ames, Univ. of $G$ a.

This paper examines the recent U.S.-Rus- sian trade dispute over poultry meat exports. The trade dispute was resolved by establishing an inspection criteria for exports to Russia and a testing protocol for salmonella and residues. Analysis indicates that Arkansas leg quarters prices are closely linked to U.S. poultry exports to Russia.

Analysis and Simulation of the U.S.-Mexican Suspension Agreement on Tomato Imports. Lewell Gunter and Glenn C. W. Ames, Univ. of Ga.

Mexico's share of the U.S. fresh winter tomato market increased from approximately $20 \%$ in $1993 / 94$ to about $30 \%$ in $1995 / 96$. Several reasons for this increase have been suggested, including NAFTA, dumping, the peso devaluation, the Mexican recession, and changes in consumer preferences. This paper provides an econometric analysis of the increase in Mexican tomato exports to the U.S.

Efficiency Enhancing Growth Policies for the Caribbean. Allen M. Featherstone, Pooran Lall, and David W. Norman, Kans. State Univ.

This study compares productive efficiency, and factors affecting it, between Caribbean and Latin American countries (1983-92). Efficiency measures were lower and more variable in Caribbean than in Latin American countries. Private and foreign investments, productive infrastructure, and education level had a positive, while inflation rate had a negative correlation with efficiency measures in both regions.

Policy Implications of an Export Tax: The Case of Cotton and Yarn in Pakistan. Darren Hudson, Miss. State Univ.; and Don Ethridge, Tex. Tech Univ.

The implications of an export tax on cotton in Pakistan in a multi-market framework are considered. Results indicate that the policy caused a net loss to the economy of $\$ 377$ million per year over the period of analysis, or about $2 \%$ the size of Pakistan's GDP. 
TITLE: Issues Influencing Agricultural Supply (Moderator: Keith Coble, Miss. State Univ.).

Georgia Cotton Acreage Response to the Boll Weevil Eradication Program. Camille M. Tribble, Christopher S. McIntosh, and Michael E. Wetzstein, Univ. of $G a$.

An adaptive regression model is employed for estimating cotton acreage response, preand post-boll weevil eradication. Results show cotton acreage becoming more inelastic to own- and cross-price changes. As a result of this shift in acreage response and yield increases from eradication, net benefits are $\$ 217.14$ per acre.

Leading Indicators for Regional Cotton Response: Structural and Time-Series Modeling Results. Paul A. Stavriotis, Jack E. Houston, Christopher S. McIntosh, and Steve C. Turner, Univ. of Ga.

Resurging southeastern cotton production compels better cotton acreage forecasts for planning seed, chemical, and other input requirements. Structural models describe leading acreage response indicators, and forecasts are compared to time-series models. Cotton price, loan rate, deficiency payments, lagged corn acreage, the PIK program, and previous cotton yield significantly influence response.

\section{Modeling U.S. Broiler Supply Response: A} Structural Time-Series Approach. Crispin M. Kapombe and Dale Colyer, W. Va. Univ.

A structural time-series model is used to estimate supply responses for U.S. broiler production. The results indicate continued importance of feed costs and technology as expressed by the stochastic trend variable. However, seasonal influences appear to have become less important since the seasonal component was not statistically significant.

Relating the Potential Impacts of an El Niño Occurrence to Southeastern Agricul- ture. Kelly H. Tiller and Daniel G. de la Torre Ugarte, Univ. of Tenn.

This research links probabilities of current El Niño strength to historical crop yield deviations to estimate current crop yield, acreage, and income impacts. Using a stochastic version of the POLYSYS national agriculture simulation model, deviations from an agricultural baseline and associated variability are estimated for the southeastern United States.

Post-Contract Plans for Conservation Reserve Program Participants: The Case of Alabama Farmers. Okmudili Onianwa and Gerald Wheelock, Ala. A\&M Univ.

Conservation reserve program (CRP) participants in Alabama were surveyed to determine the probable utilization of CRP acres should the contracts expire without opportunity for renewal. From over 9,000 contracts established between 1986 and 1995, 594 contracts were randomly selected for the study. Results indicate that $90 \%$ of CRP tree acres would be retained in trees, while nearly $60 \%$ of CRP grass acres would be converted to row crop production.

TITLE: Meat Markets and Trade (Moderator: Glenn C. W. Ames, Univ. of Ga.).

The Importance of Meat Exports as a Source of U.S. Feed Grain Demand. Richard L. White, Daniel G. de la Torre Ugarte, and Daryll E. Ray, Univ. of Tenn.

Indirect corn and soybeans exported through beef, pork, and broilers are estimated by converting meat exports for 1995-2007 into corn and soybean meal feed. Acreage requirements also are estimated. Results suggest meat export growth could be an important source of future demand for feed grains.

Seasonality of the Poultry Processing Industry. Ronald A. Schrimper, N.C. State Univ.

Seasonal fluctuations in labor utilization in the poultry processing industry have been 
much smaller in recent years relative to 10 or 20 years earlier. The decrease in seasonal variablity in the number of employees has been greater than the decrease in seasonal changes in the hours of work per week.

Spatial Equilibrium in the U.S. Swine-Pork Sector with Exogenous Trade. Joseph E. Williams, Chang-Gil Kim, Derrell Peel, and Clement Ward, Okla. State Univ.

Production, processing, and transportation costs of live hogs and pork impact location of production-processing facilities, productionprocessing and consumption quantities, and hog/pork shipment patterns. Live hog/pork imports/exports impact prices in production and consumption regions. A GAMS program is used to determine optimal production, processing, consumption, and transportation patterns with exogenous trade.

TITLE: Active Learning Methods in Agricultural Economics (Moderator: Larry Falconer, Tex. A\&M Univ.).

\section{Student Learning on Multistage Market} Simulation. Fred $C$. White, Univ. of $G a$.

This paper describes and evaluates the multistage market simulation, which helps develop problem-solving skills. Student responses indicate improved understanding of price discrimination and government policy impacts on a multistage market. Regression results show a statistically significant relationship between financial performance and exam scores, as a conventional measure of student learning.

Agribusiness: How Do We Teach and Research if Our Approaches Differ? Steven W. Martin, Garry Smith, Juan Batista, and Lisa House, Miss. State Univ.

Agribusiness has become the "term" in teaching and research today. A simple review of journal articles revealed $68 \%$ of agricultural journal articles were sector oriented, $23 \%$ policy oriented, and $9 \%$ firm oriented. Business journal articles were $73 \%$ firm oriented, $24 \%$ sector oriented, and $3 \%$ policy oriented.

Teaching Bank Management Principles Using Oklahoma Bank Simulation. Chris Petermann, Harry Mapp, and Ross Love, Okla. State Univ.

Oklahoma bank simulation (OBS) represents the competitive environment of rural commercial banks. Management teams establish deposit and loan interest rates, service charges, advertising expenses, loan officer and employee salaries, desired loan volumes, and investment strategies each period of play. Accumulated net income, portfolio composition, and serving the community are performance measures.

TITLE: Improving Performance in the Agribusiness System (Moderator: Bob Nelson, Auburn Univ.).

\section{Reexamining Wheat Cleaning Decisions at} County Wheat Elevators. Roy Attaway, Phil Kenkel, Conrad Lyford, and Kim Anderson, Okla. State Univ.

This paper presents a mathematical programming model of wheat cleaning decisions at county elevators. While previous studies have used countywide estimates of commingled wheat, this study uses two years of actual truckload data to run the simulations. In the model, wheat cleaning was feasible in one of the harvest years.

Export Status and Assistance Needs of U.S. High-Value Agribusiness. Kim Jensen, Univ. of Tenn.; and Scott Hollis, USDA/NASS.

This study examines export assistance needs of agribusinesses across export status. Exporters are categorized into high involvement, low involvement, and export intenders. The study also examines how firm characteristics, such as size, influence export status, including nonexporter/nonintenders. Data were obtained through a 1995 survey of agribusinesses. 
Initiating an Industry Strategic Planning and Coordination Effort: Rationale, Method, and Practice. Conrad Lyford, Okla. State Univ.; Donald Ricks and Christopher Peterson, Mich. State Univ.; and Timothy Woods, Univ. of Ky.

Industry strategic planning and coordination (ISPC) is an approach that some agricultural commodity industries are using to proactively address and facilitate adjustments to changing competitive situations. While there are many aspects of ISPC, this paper focuses on the challenge of initiating or starting such a process.

Biotechnology, Identity-Preserved Crop Systems, and Economic Value. Richard Maltsbarger and Nicholas Kalaitzandonakes, Univ. of Mo.

Agricultural biotechnology is generating a variety of grains with enhanced composition and value. This paper focuses on supply chains designed to preserve grain identity and capture rents from biotechnology innovation. Key drivers in the development of identitypreserved grain systems and in the evolution of relevant supply chains are discussed.

Technical Efficiency of Food and Kindred Products Firms in the U.S. Saravuth Sok, Dean Schreiner, and Dan Tilley, Okla. State Univ.

This study evaluates the economic competitiveness of food and kindred products at the state level by estimating relative efficiency indices using corrected ordinary least squares (COLS) techniques. Measures of states' technical efficiency at the three-digit SIC level are compared to the frontier. Mean values ranged from $57 \%$ for meat products to $86 \%$ for preserved fruits and vegetables.

TITLE: Rural Households and Poverty (Moderator: Lynn Reinschmiedt, Miss. State Univ.).

Household Characteristics and the Use of
Information Technology in Rural Areas: Bivariate Probit Estimates. Stephan J. Goetz, Univ. of Ky.; and Peter Schirmer, The Ky. Long-Term Policy Res. Center.

Bivariate probit methods with sample selection are used to model joint decisions of information technology adoption, such as the use of computers and e-mail features. The results show that household socioeconomic characteristics, including rural/urban residence, have significant effects on information technology adoption.

The Determinants of Regional Income Distribution in the South, 1980-90: The Roles of Interregional Migration and Human Capital Accumulation. Octavian Ngarambe, Univ. of $K y$.

This paper examines simultaneously the effects of net migration and education on blackto-black, white-to-white, and overall income inequality. Results indicate that net migration reduced inequality within both racial groups and reduced overall income inequality. Educational growth is also found to have a negative effect on black and overall income inequality.

An Economic Analysis of Household Income of Farm Families in West Virginia. Michael Satin and Tesfa G. Gebremedhin, W. Va. Univ.

An ordinary least squares (OLS) regression method was used to evaluate the relative importance of some social and economic characteristics that contribute to the explanation of off-farm employment participation in rural communities in West Virginia. The study confirms that the trend is for greater reliance on off-farm income, and farming is no longer the sole means for economic livelihood of farm families.

Determinants of Poverty Status in Rural Southern Illinois. Joyce E. Allen-Smith and Michelle L. Eley, Univ. of Ill. at Urbana. 
Some aspects of uneven development theory hold for southern Illinois. The region has a history of primary extraction, low level of industrialization, and relatively high poverty rates. Using data from the 1990 Census of Population and Housing, a qualitative choice model is developed to analyze the determinants of poverty status and deep poverty status among rural families.

TITLE: Environmental Policy and Input Management (Moderator: Ron Fleming, Univ. of Ky.).

\section{Environmental Quality and Farm Income} Tradeoffs in Rockingham County, North Carolina. Godfrey C. Ejimakor, N.C. A\&T State Univ.

An optimization model was used to constrain levels of soil loss and chemicals on limited resource and average-sized farms. Pesticides were found to be the most limiting input. Controlling this pollutant reduces net farm income and limits the use of other pollutants such as soil loss, nitrogen, and phosphates.

\section{Demand for Fertilizer and Other Farm In-} puts in Kansas: Implications for Fertilizer Reduction Policy Instruments. Ephraim Nkonya and Terry Kastens, Kans. State Univ.

Elasticity of demand for inputs in Kansas were estimated using a translog cost function. Demands for fertilizer, chemicals, capital, and other inputs are price inelastic, implying that increasing their prices through taxation or other policy instruments will have limited impact on reduction of their demand. Hence, policy instruments other than price should be considered.

Combining Farm Management and Ecosystem Management: Insights from Representative Farm Models in a Conservation Priority Watershed. Jeff Beaulieu, Steven $E$. Kraft, and Phillip Letting, Southern Ill. Univ.

Representative-farm, linear programming in the Cache River Watershed, Illinois, dem- onstrates constraining soil loss to $2 \mathrm{~T}$ results in changed tillage practices, modestly reduced farm income, but impressive soil loss reductions. Constraining to $\mathrm{T}$ results in more significant income penalties. This may explain the popularity of alternative conservation systems under conservation compliance.

TITLE: Livestock and Waste Management Issues (Moderator: Patricia E. Norris, Mich. State Univ.).

Financial Analysis of Selected Setpoints for Broiler Houses. Randall D. Little, J. May, J. Simmons, and B. Lott, Miss. State Univ.

Energy expenditures are a major component of costs growers face in broiler production. High environmental temperatures hinder rates of growth and feed efficiency. This paper evaluates the financial response of maintaining in-house temperatures at selected setpoints. The results suggest that financial incentives exist for maintaining cooler broiler house temperatures.

An Empirical Analysis of Cross-Breeding in Swine. Tom E. Anton, Univ. of Ill.; and $G$. Traxler, D. Kuhlers, W. Prevatt, and S. Jungst, Auburn Univ.

Cross-breeding is used by producers to increase the productivity of their swine operation. Because of increased heterosis, terminal systems have production benefits over rotational systems. However, the terminal crossbreeding system includes an added cost for purchasing replacement gilts. We examine the relative profitability of the two different crossbreeding systems.

Effect of Location, Concentration, and Waste Value Differences upon Livestock Waste Disposal Decisions. Glenn A. Helmers, Univ. of Nebr.; Raymond E. Massey, Univ. of Mo.; and Gary W. Lesoing, Univ. of Nebr.

An integer programming model of livestock waste disposal was constructed, emphasizing location alternatives combined with cost 
estimates by distance and application rate. This enabled analyses to be made of location, waste concentration levels, and application rates on optimum disposal strategies. Allowance was made for three waste values in the analysis.

TITLE: Factors Affecting Food Purchases (Moderator: Kim Jensen, Univ. of Tenn.).

On the Consumers' Use of Nutritional Labels. Rodolfo M. Nayga, Tex. A\&M Univ.; Daria Lipinski, Cornell Univ.; and Nitin Savur, Rutgers Univ.

Food choices are influenced by use of labels both while food shopping and while at home preparing meals. Three models are developed to represent label use while food shopping, label use while preparing food at home, and label use to compare nutrients of different brands while shopping.

Consumer Knowledge of the Nutrient Content of Selected Fresh Meat Cuts. Alvin Schupp and Jeffrey Gillespie, La. State Univ.; and D. Reed, Tex. A\&M Univ.

A recent survey of Louisiana households provided estimates of their knowledge of the fat, cholesterol, and protein content of selected combinations of fresh beef, pork, chicken, and turkey cuts. Limited dependent variable and tabular analyses were used to assess the impacts of socioeconomic characteristics of households on nutrition knowledge of selected fresh meat cuts.

Factors Affecting Fat, Calories, Sodium, and Sugar Intake. Yue Lai, Wojciech Florkowski, and Chung L. Huang, Univ. of Ga.

Probit analyses indicate that intake of sodium and sugar was, while intake of fat and calories was not, affected by socioeconomic and demographic factors. Vegetable perceptions and consumption influenced intake of all four dietary elements. Findings can be applied to improving health education and vegetable marketing campaigns.
An Analysis of Factors Influencing Consumer Purchases at Farmers' Markets. Donald R. McDowell and Raphael O. Okafor, N.C. A\&T State Univ.

Farmers' markets are alternative outlets for purchasing fresh food, crafts, garden supplies, etc. This study presents findings of a survey administered to 170 visitors at farmers' markets during the summer of 1995 . A Tobit mod$\mathrm{el}$ is employed to determine the influence exerted by selected contextual variables on visitors' decisions to purchase products at farmers' markets.

\section{A Logit Analysis of Socioeconomic Factors Influencing Milk Consumption in Louisiana by Product Type. Lynn E. Dellenbarger and Lihong Z. Dellenbarger, La. State Univ.}

Research has been conducted by the agricultural economics profession on milk consumption without looking at who is consuming the milk and the reliability of the underlying data. This paper addresses why the researcher is using logit analysis instead of another statistical technique such as Tobit analysis.

TITLE: Capital Structure (Moderator: Bruce Ahrendsen, Univ. of Ark.).

A Reexamination of the Portfolio Effects on Domestic Farmland. Andrew Schmitz and Charles Moss, Univ. of Fla.

This study reexamines the Darby and Feldstein effects on agricultural real estate values from 1963-95. The results indicate little support for either effect. Further, splitting the sample to adjust for the Tax Reform Act of 1986, while significant, adds no support for either hypothesis.

Determination of Optimal Capital Structure in Agricultural Cooperatives. Joseph $L$. Parcell, A. Featherstone, and D. Barton, Kans. State Univ.

The theory of optimal leverage suggests 
the cost of cooperative debt is less than the cost of equity capital. This tradeoff is eventually reflected in the choice between offering products and/or services at the lowest possible margin without regard to risk, versus maintaining higher margins to ensure a secure ongoing business. This analysis determines the optimal level of leverage that ensures a competitive return on equity and simultaneously provides financial risk protection.

Cross-Section Evidence of the Risk-Balancing Debt Formulation. Charles Moss, Univ. of Fla.; and Timothy G. Baker, Purdue Univ.

Recent changes in agricultural policy may imply significant changes in risk for the farm sector. This study examines the change in financial response to risk using cross-sectional data. The results suggest that aggregate risk aversion in the domestic farm sector has significantly declined over time.

The Effect of Changes in the Structure of Banking on the Cost of Capital in Agriculture: A Differential Approach. James Seale, Jr., and Charles Moss, Univ. of Fla.; and Allen M. Featherstone, Kans. State Univ.

The U.S. banking industry has undergone significant economic and regulatory changes in recent years. This study develops a multiproduct, differential supply system, fits it to 1995-96 agricultural banking data, and presents initial results. Several alternative specifications are suggested for analyzing the significance of recent changes in the banking environment.

TITLE: Resource Valuation and Demand (Moderator: Hector Zapata, La. State Univ.).

An Analysis of Residential Demand for Electricity in the United States. Panadtorn Mahakusol and Tesfa G. Gebremedhin, W. Va. Univ.

Ordinary least squares (OLS) regression was applied to evaluate the residential demand for electricity in the U.S. The explanatory variables exhibit effects in the hypothesized direction and significantly affect the demand for electricity. Electricity consumption trends upward with time. The positive cross-price elasticity of demand indicates that natural gas is a substitute energy for electricity.

Joint Production and Averting Expenditure Measure with WTP: Do Bottled Water Expenditures Really Measure Avoidance Costs? Bryan J. Hubbell and Jeffrey L. Jordan, Univ. of $G a$.

An averting behavior model is estimated to examine whether bottled water purchases reflect both aversion and tastes. Probit estimation indicates dissatisfaction with quality and concern about safety have positive impacts on the choice to purchase bottled water. Adjusting averting expenditures for tastes resulted in reductions in averting costs of $15 \%$.

A Conceptual and Empirical Approach to Valuing Biodiversity. Jack Coburn Isaacs, Northeastern La. Univ.; and E. Jane Luzar, La. State Univ.

This research develops and tests a model of resource valuation of passive use values related to biodiversity in a region of the Lower Mississippi Valley Ecosystem. Biological diversity is described in terms of ecological endpoints. The probability of being willing to pay to preserve biodiversity in the study area was empirically analyzed using a single-bound dichotomous choice framework.

Analyzing Conjunctive Use of On-Farm Reservoirs and Irrigation Wells in the Arkansas Delta. Kenneth B. Young, E. Wailes, and J. Smartt, Univ. of Ark.

A simulation model is applied to determine optimal sizes of on-farm reservoirs under varying groundwater and other conditions. Economic justification was found for on-farm reservoirs as groundwater depletion reached a critical threshold. Optional reservoir size was not sensitive to varying crop prices. 
TITLE: Evaluating Tools to Manage Risk (Moderator: Ram Acharya, Auburn Univ.).

Adoption of Real-Time Weather Information by Agricultural Decision Makers. $W$. Lucius, P. Kenkel, and J. D. Carlson, Okla. State Univ.

New information tools are playing increased roles in agribusiness and other areas of society. Agricultural producers and agribusiness professionals have lagged in their adoption of electronic weather information. Extension agents were more likely to use the information system and the World Wide Web, but failed to promote adoption.

Evaluating Crop and Revenue Insurance Purchase Decisions in the Mid-South. Stan Spurlock, Barry Barnett, Swati Dhar, Olga Isengildina, Somporn Meerungruang, Gerald Mumma, and Olga Murova, Miss. State Univ.

A whole-farm financial simulation model is used to estimate probability distributions of ending net worth under various crop and revenue insurance scenarios for a representative Mid-South cotton-soybean farm. Under current rate structures, the highest levels of insurance coverage increase the probability of farm insolvency.

Factors that Influence Yield Insurance Purchasing Decisions by Small-Scale Grain Producers in South Carolina. K. Selvavel, Claftin College; S. Sureshwaran and E. Onunkwo, S.C. State Univ.; and J. Nyankori, Clemson Univ.

Few studies have examined the relationship between yield insurance and the use of another risk management tool. Results from a logit model suggest that crop insurance purchasing decisions are influenced by the use of pricing tools by small-scale grain farmers in South Carolina.

TITLE: Renewable Resources (Moderator: E. Jane Luzar, La. State Univ.).
Aggregation of Species Catch Rates and Target Groups in Random Utility Models of Marine Recreational Fishing. Peter W. Schuhmann, Univ. of Richmond.

A nested random utility model of site choice and target species selection is estimated using alternative levels of species aggregation. The degree to which welfare results of stockenhancement policies may be dependent upon species aggregation is analyzed by comparing willingness to pay for hypothetical catch rate changes across the models.

Optimal Forest Management Regimes with Multiple Products, Stochastic Sawtimber Prices, and the Chance of Physical Stand Loss. Charles Jacques and Arthur Stoecker, Okla. State Univ.

Dynamic programming, with timber prices and stand life stochastic, was used to determine optimal management decisions for stands of loblolly pine. Optimal strategies included harvesting immature trees if their current value was higher than expected future value (EFV) and holding mature trees if their current value was less than EFV.

Improved Management of the U.S. North Atlantic Swordfish Fishery. Sherry L. Larkin, Donna J. Lee, and Charles M. Adams, Univ. of Fla.

A bioeconomic model was developed for the U.S. Atlantic swordfish fishery. Results indicate that net returns to the fishery are increased by reducing fleet size or lowering the mortality of incidentally caught juveniles. Regulators need to jointly consider such policies, however, since reducing juvenile mortality increases the optimal fleet size.

Ex-Vessel Shrimp Prices Landed from the Gulf of Mexico. Dhazn Gillig, Oral Capps, Jr., and W. L. Griffin, Tex. A\&M Univ.

U.S. Gulf of Mexico ex-vessel prices for small, medium, and large shrimp, as well as imports, were analyzed using monthly time- 
series data for the period 1981-99. Owner flexibilities ranged from -0.0663 to -0.1027 . Imports from South America are substitutes for Gulf shrimp. Structural changes and seasonal variation were evident.

TITLE: Policy Issues Affecting Agribusiness (Moderator: Conrad Lyford, Okla. State Univ.).

Sustainable Agriculture: Potential Implications for the Agricultural Input Sector. Daniel G. de la Torre Ugarte, Kelly H. Tiller, and Stephen P. Slinsky, Univ. of Tenn.

This research estimates the economic impacts of extensive adoption of environmentally sustainable agricultural practices on the agribusiness input sector, including the change in expenditures for seed, fertilizer, herbicide, insecticide, labor, machinery, and irrigation. Additionally, relationships among acreage assignment, cropping practices, and expenditures for selected regions in the southeastern United States are examined.

Willingness to Pay for Increased Food Safety Among Food Service Directors. John N. Giamalva, Martin Redfern, and William $C$. Bailey, Univ. of Ark.

Patients in hospitals and long-term care facilities are at increased risk of foodborne disease. A national survey of food service directors in these facilities found that a majority favored a HACP approach to increasing food safety. Fewer were willing to pay for chemical treatments or irradiation. Willingness to pay was a function of patients over 65 years of age, under five years, or immune-compromised, and gender of the respondent.

The Political Economy of Bt Cotton: Property Rights, Transactions Costs, and Imperfect Information. Barry $J$. Barnett and Brandon O. Gibson, Miss. State Univ.

The commercialization of transgenic crop technologies is expanding rapidly. In order for society to benefit fully from these technologies potential "market failures" must be anticipated and addressed. Based on the case of Bt cotton, this paper identifies important future research issues related to property rights, transactions costs, and imperfect information.

TITLE: Topics in Rural Economics (Moderator: Timothy A. Woods, Univ. of Ky.).

The Economic Impact of Farm-Raised Catfish Production in Southern Rural Communities. James Swindell, Jr., S. Sureshwaran, and L. House, Miss. State Univ.

Catfish farming has been a viable and profitable opportunity for many southern farmers and has provided employment, income, and growth in rural communities. Catfish processing requires large amounts of startup capital. Capital budgeting methods are used to forecast profitability of various sized processing facilities.

Factors Affecting Social Capital: Evidence from the Rural South. Anil Rupasingha and David Freshwater, Univ. of Ky.

Social capital plays an important role in explaining the path of development in communities. The attitudes of rural southerners are examined using an econometric model that explains the degree of civic engagement in terms of an array of variables that are theoretically important predictors of levels of social capital. In rural areas, local cooperation is the most likely substitute for the direct provision of social services by the government.

Consolidating Rural School Districts: Potential Savings and Effects of Student Achievement. B. Wade Brorsen and Charles Jacques, Okla. State Univ.

Consolidating rural school districts has been proposed by policy makers to save money by obtaining economies of size. Results indicate that economies of scale with respect to expenditures per student exist up to an average daily membership (ADM) of 1,070 students, 
but that as school districts become larger, test scores decline.

Economic Development Incentives and Economic Growth. Daniel $V$. Rainey, Clemson Univ.

States have offered business incentives to lure prospective new manufacturing establishments or retain existing ones. This study provides insights into the relative impact of business incentives on overall economic growth. A cross-sectional time-series model is developed to examine the importance of taxes and development incentives relative to other community-specific characteristics.

Impacts of New Agricultural Technology on the Real Growth in the U.S. and Kentucky Farm Economy, 1949-95. David L. Debertin, Univ. of $K y$.

This paper examines the impacts of new technology on the U.S. and Kentucky farm economy over the 1949-95 time period. Results reveal that new technologies have not made farmers in the aggregate better off if their well-being is measured in terms of growth in aggregate farm income.

TITLE: International Production and Consumption Issues (Moderator: Warren Couvillion, Miss. State Univ.).

The Performance and Validity of Alternative Measures of Health Information in a Demand Model for Fats and Oils in Japan. Sam-Ryang Kim and Wen S. Chern, Ohio State Univ.

This study investigates the major factors affecting the demand for fats and oils under the possible influence of health information in Japan. The newly developed fat and cholesterol information index appears to reflect the changing health information on fat and cholesterol much better than the ad hoc cumulative index.

The Impacts of El Niño on World Rice Production, Consumption, and Trade. James Hansen, Eric Wailes, and Gail Cramer, Univ. of Ark.

El Niño's consistent weather anomalies affect some of the major rice producing countries: Indonesia, Australia, Philippines, Sri Lanka, India, and Brazil. This information is applied to a 23-country econometric model of the world rice economy to assess the impact of El Niño on major rice producing, consuming, and trading countries.

Rural Household Food Consumption in South and North China. Cheng Fang, Eric J. Wailes, and Gail L. Cramer, Univ. of Ark.

A two-stage budgeting LES-AIDS system is used to estimate China's north and south rural consumption patterns using pooled household data from the rural household survey, 1986-96. Results show that there are significantly different consumption patterns between the two regions.

Household Demand in Urban China: A Three-Stage AIDS Model. Haiyue Nie and Michael Hammig, Clemson Univ.

An AIDS model of Chinese urban households was estimated with pooled provincial and time-series data. Results imply that China plays a large role in the world wheat market, and market behavior differs between North and South China. 